\title{
TROCAS GASOSAS INFLUENCIAM NA MORFOGÊNESE in vitro DE DUAS CULTIVARES DE OLIVEIRA (Olea europaea L.) ${ }^{1}$
}

Marcos Vinícius Marques Pinheiro², Fabrina Bolzan Martins ${ }^{3}$, Aloisio Xavier ${ }^{4}$ e Wagner Campos Otoni ${ }^{5}$

\begin{abstract}
RESUMO - Os objetivos deste trabalho foram estabelecer in vitro as cultivares de oliveira 'Arbequina' e 'Maria da Fé' e avaliar a influência das tampas com membranas permeáveis a gases na morfogênese in vitro dessas cultivares. Inocularam-se segmentos nodais com gemas previamente descontaminadas pelo protocolo aqui desenvolvido. Utilizaram-se o delineamento inteiramente casualizado (DIC) em esquema fatorial $2^{3}$, duas cultivares; dois meios de cultura OM (Olive medium) $(\mathrm{OM}+20 \mu \mathrm{M}$ de zeatina [1]; e OM + $20 \mu \mathrm{M}$ de zeatina $+10 \mu \mathrm{M}$ de $\mathrm{GA}_{3}[2]$ ); dois tipos de vedação (tampa rígida sem orifício e com membrana porosa) com cinco repetições/ tratamento; e a unidade experimental constituída por quatro tubos de ensaio. Avaliaram-se: a porcentagem de contaminação total; a porcentagem de contaminação fúngica e bacteriana; o número de gemas intumescidas; o número de brotos; e a porcentagem de oxidação. Aos 30 dias de cultivo, constatou-se a contaminação de $15 \%$ e 8,8\% dos explantes de 'Arbequina' e 'Maria da Fé', respectivamente. Em 'Arbequina', 33,3\% e 66,7\% ocorreram por contaminação fúngica e bacteriana, respectivamente. Em 'Maria da Fé', 28,6\% e 71,4\% decorreram de contaminação fúngica e bacteriana, respectivamente. O número de gemas foi superior $(\mathrm{p}<0,05)$ em 'Arbequina', comparativamente à 'Maria da Fé', quando se utilizou tampa com membrana porosa para vedar os frascos. Em tampa rígida não houve diferença entre cultivares. O número de brotos no meio 1 foi superior estatisticamente $(\mathrm{p}<0,05)$ ao no meio 2. Não houve diferença estatística em porcentagem de oxidação. Sugere-se a utilização do protocolo de desinfestação aqui desenvolvido, como também do meio 1 e tampas com membranas porosas, pois isso favorecerá o desenvolvimento das gemas e a posterior formação de plantas.
\end{abstract}

Palavras-chave: ‘Arbequina', 'Maria da Fé’, Membranas porosas, Reguladores de crescimento.

\section{GAS EXCHANGE AFFECTS in vitro MORPHOGENESIS OF TWO OLIVE CULTIVARS (Olea europaea L.)}

\begin{abstract}
The objectives of this work were to establish cultivars of Olea europaea L., namely 'Arbequina' and 'Maria da Fé', and to evaluate the influence of gas exchange on in vitro morphogenesis of these cultivars. Under aseptic conditions, single-bud nodal segments were previously decontaminated using disinfestation protocol developed in this work. The treatments followed a completely randomized design, in a $2^{3}$ factorial scheme: two cultivars and two olive (Olive medium) culture media (OM) (OM + 20 $\mu$ M zeatin [1]; and

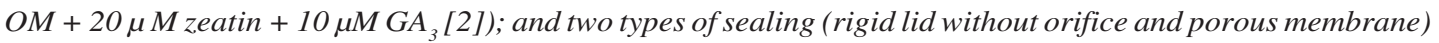
in five repetitions/treatment. The experimental unit consisted of four tubes. The following parameters were assessed: percentage of total contamination; percentage of fungal and bacterial contamination; number of explants with swollen buds; number of axillary buds, and oxidation percentages. At 30 days of cultivation, the total contamination indexes of $15 \%$ and $8.8 \%$ were recorded for 'Arbequina' and 'Maria da Fé', respectively. For bacterial and fungal contamination percentages, respectively, 'Arbequina' had $33.3 \%$ and $66.7 \%$, whereas 'Maria da Fé' presented $71.4 \%$ and $28.6 \%$. Regarding the number of responsive cultures showing swollen buds, there was no difference between cultivars when rigid lids without porous membranes were used. However,
\end{abstract}

\footnotetext{
${ }^{1}$ Recebido em 06.12.2011 aceito para publicação em 20.12.2012

${ }^{2}$ Laboratório de Cultura de Tecidos Vegetais/BIOAGRO, Universidade Federal de Viçosa, MG, Brasil. E-mail: <macvini@ gmail.com>.

${ }^{3}$ Instituto de Recursos Naturais da Universidade Federal de Itajubá, UNIFEI, Brasil. E-mail: <fabrinabm@gmail.com>.

${ }^{4}$ Departamento de Engenharia Florestal da Universidade Federal de Viçosa, UFV, MG, Brasil. E-mail: <xavier@ufv.br>.

${ }^{5}$ Departamento de Biologia Vegetal da Universidade Federal de Viçosa, UFV, MG, Brasil. E-mail: <wcotoni @ gmail.com>.
} 
lids with porous membranes led to statistically superior values for 'Arbequina' as compared to 'Maria da Fé. For the number of shoots, culture medium 1 was statistically superior to 2. There was no statistical difference for oxidation percentages among treatments. Thus, because of the low level of contamination, it is suggested to use the disinfestation protocol developed in this work. In addition, the use of culture medium 1 and lids with porous membranes did favoured further development of axillary buds into plants.

Keywords: 'Arbequina', Growth regulators, 'Maria da Fé', Porous membranes.

\section{INTRODUÇÃO}

A família Oleaceae é composta por 30 gêneros, destacando-se o gênero Olea L., que consiste de 30 espécies distribuídas pela Europa, Ásia e África (RUGINI, 1995; LOUREIRO et al., 2007). Dentro do gênero Olea sp., destaca-se a espécie Olea europaea L., popularmente conhecida como oliveira, sendo cultivada, principalmente, na bacia do Mediterrâneo, embora sua área de distribuição esteja sendo estendida para diversos países do mundo, como Austrália, China e países da América do Sul (RUGINI, 1995; RUGINI; GUTIÉRREZPESCE, 2006). Na América do Sul, o Chile e a Argentina destacam-se como principais países produtores e exportadores de azeitona e azeite. No entanto, o Brasil ainda não possui plantios comerciais de oliveira, ficando praticamente dependente da importação de seus derivados (VIEIRA NETO et al., 2008). Dessa forma, é um dos maiores importadores de produtos da oliveira da América do Sul, sendo a Argentina um dos maiores fornecedores, incluindo também Espanha e Portugal (VIEIRA NETO et al., 2008).

As oliveiras e as espécies selvagens desse gênero são geralmente consideradas tolerantes às condições ambientais desfavoráveis, como verões intensos (seca), doenças e fogo, além de terem excelentes adaptações a diferentes situações edáficas, tornando-se um gênero bastante atrativo e muito utilizado em programas de reflorestamento de regiões ameaçadas (RUGINI et al., 2000; BRITO et al., 2008). Vários programas de melhoramento genético estão sendo executados em todo o mundo, visando ao aumento de produção, à melhoria do teor e da qualidade do óleo, à modificação do comportamento do crescimento vegetativo e à tolerância a vários estresses bióticos e abióticos (PÉREZBARRANCO et al., 2009). No entanto, a escassez de pesquisas com espécies do gênero Olea sp. no Brasil impede a viabilização e o cultivo econômico da oliveira (OLIVEIRA et al., 2003; VIEIRA NETO et al., 2008). Nesse sentido, devem ser realizadas, primeiramente, pesquisas com relação à produção de mudas de oliveira.
Uma das formas de produção de mudas é através da técnica de propagação vegetativa (TRABELSI et al., 2011), por meio de rebentos enraizados, enxertia ou por estaquia. Outra forma de produção de mudas é por propagação seminífera (sementes). Porém, esse tipo de propagação é dificultado por diversos motivos, entre os quais a longa fase juvenil e a elevada heterozigose das progênies e o baixo nível de frutificação, além da germinação lenta das sementes (ACEBEDO et al., 1997).

Outro método de produção de mudas que vem sendo bastante utilizado é a propagação in vitro, e, para o estabelecimento da cultura nessas condições, utilizam-se, principalmente, explantes de segmento nodal (RUGINI et al., 2000). A principal vantagem dessa técnica são a diminuição do tempo de formação das mudas e a obtenção de material genético com qualidade genéticosanitária superior aos outros métodos de produção de mudas citados anteriormente (OLIVEIRA et al., 2006).

Com isso, a propagação in vitro torna-se estratégia de propagação vegetativa muito importante, podendo capturar a variação genética nos programas de melhoramento florestal, como também em programas de multiplicação (LOPES et al., 2006). No entanto, a propagação de plantas lenhosas por cultivo in vitro é limitada devido à interferência de contaminantes, por bactérias e fungos; pela oxidação dos explantes, principalmente por compostos fenólicos; baixa multiplicação e crescimento das plântulas; sensibilidade às trocas gasosas; e ao acúmulo de etileno dentro dos frascos de cultivo (RODRIGUES et al., 2011).

A propagação in vitro, quando utilizado o sistema de vedação convencional, previne a desidratação de plantas e do meio de cultura, além de evitar a contaminação. No entanto, nesse tipo de vedação ocorrem elevada concentração de etileno e reduzida concentração de $\mathrm{CO}_{2}$; restringem-se o fluxo de fótons fotossinteticamente ativos e as trocas gasosas, diminuindo as taxas de transpiração e a fotossíntese das plantas; dificulta-se a absorção de água e nutrientes, 
causando redução da taxa de crescimento dos explantes e, assim, elevadas perdas durante a aclimatização, devido à mortalidade das plantas (NGUYEN; KOZAI, 2005; ZOBAYED, 2006; XIAO et al., 2011). Dessa forma, o ideal para a propagação in vitro seria manter as mesmas condições ambientais, como os níveis ideais de fluxo de fótons fotossinteticamente ativos, a concentração de $\mathrm{CO}_{2}$ (XIAO et al., 2011), a manutenção das trocas gasosas, entre outros. Para isso, vem sendo utilizadas membranas porosas permeáveis a gases, pois permite a eficiência das trocas gasosas, diminuindo o acúmulo de etileno e, assim, facilitando a aclimatização das plantas produzidas (XIAO et al., 2011). Kozai e Kubota (2001) relataram que as mudanças no microambiente dos frascos de cultura, promovidas pelas trocas gasosas, favorecem a manutenção da concentração de $\mathrm{CO}_{2}$, estimulam a fotossíntese e reduzem a concentração de etileno e a umidade relativa dentro dos frascos de cultivo.

Dessa forma, o objetivo deste estudo foi estabelecer duas cultivares de O. europaea ('Arbequina' e 'Maria da Fé') em condições in vitro, além de avaliar a influência do tipo de vedação na morfogênese in vitro dessas duas cultivares.

\section{MATERIAL E MÉTODOS}

\subsection{Local de realização do experimento e material vegetal}

Este trabalho foi realizado no Laboratório de Cultura de Tecidos II do Instituto de Biotecnologia Aplicada à Agropecuária (BIOAGRO), da Universidade Federal de Viçosa (UFV), localizado no Município de Viçosa, MG. Utilizaram-se duas cultivares de O. europaea, 'Arbequina', amplamente utilizada para a produção de azeite; e 'Maria da Fé', obtida por melhoramento genético realizado pela Empresa de Pesquisa Agropecuária de Minas Gerais (EPAMIG). A cultivar 'Arbequina' foi proveniente de estaquia, e a cultivar 'Maria da Fé' foi proveniente de enxertia. As plantas-matrizes das duas cultivares de oliveira provenientes da EPAMIG, da cidade de Maria da Fé, MG foram mantidas em casa de vegetação do Departamento de Biologia Vegetal da UFV.

\subsection{Estabelecimento in vitro das cultivares de oliveira}

Para o estabelecimento in vitro, foram utilizados segmentos nodais provenientes de brotações novas e vigorosas de oliveiras 'Arbequina' e 'Maria da Fé', mantidas em casa de vegetação. Visando à manutenção das cultivares e à prevenção de ataque por patógenos, procedeu-se à pulverização de óleo mineral (Assist ${ }^{\circledR}$ ) na concentração de $10 \mathrm{~mL} \mathrm{~L}^{-1}$, a cada 20 dias. Ramos entre 10-15 cm foram excisados (Figura 1A) com tesoura de poda previamente desinfestada em hipoclorito de sódio (2,5\% de cloro ativo), então levados ao laboratório, onde foram cortados $2 / 3$ do comprimento das folhas e deixado $1 / 3$ da folha próximo ao pecíolo. O material foi lavado, inicialmente, em detergente neutro, por $10 \mathrm{~min}$, permanecendo imerso em água corrente, por $3 \mathrm{~h}$.

Após esse processo, os explantes foram imersos em solução de antibiótico Agrimicina e de fungicida Mancozeb na concentração de $1 \mathrm{~g} \mathrm{~L}^{-1}$, permanecendo, em seguida, imersos em água corrente, por $30 \mathrm{~min}$, para a retirada gradativa da solução. Os explantes foram, ainda, mantidos em solução de ácido ascórbico (100 $\left.\mathrm{mg} \mathrm{L}^{-1}\right)$ e ácido cítrico $\left(150 \mathrm{mg} \mathrm{L}^{-1}\right)$, para evitar a oxidação. Em câmara de fluxo laminar, o material foi desinfestado com imersão em álcool $70 \%$ por aproximadamente 1 min, seguido de imersão em solução de hipoclorito de sódio (2,5\% de cloro ativo), adicionado de duas gotas de Tween ${ }^{\circledR} 20$, durante 15 min. Após esse período, o material foi enxaguado por três vezes em água destilada autoclavada por 5 min. A partir daí foi cortado 1/3 restante das folhas, na base do pecíolo, deixando-se apenas os segmentos nodais com aproximadamente $1 \mathrm{~cm}$ de comprimento (Figura 1B).

Após 30 dias de cultivo, foram avaliadas a porcentagem de contaminação total e a porcentagem de contaminação fúngica e bacteriana das cultivares de O. europaea, 'Arbequina' e 'Maria da Fé'.

\subsection{Estimativa do número de trocas gasosas por minuto}

Antes do estabelecimento in vitro das cultivares de $O$. europaea, realizou-se a mensuração das trocas gasosas. Para tanto, o headspace (espaço livre) de cada tubo, contendo os diferentes tipos de vedação (tampa rígida de polipropileno sem orifício; e tampa rígida de polipropileno com orifício coberto por membrana porosa), foi saturado com uma mistura de dióxido de carbono $\left(\mathrm{CO}_{2}\right)$ na concentração de $1 \%$. As leituras da concentração de $\mathrm{CO}_{2}$ no interior dos tubos foram realizadas nos tempos de $0,5,10,15$ e 20 min. Para tal, utilizou-se uma seringa esterilizada de $1 \mathrm{~cm}^{3}$ para a coleta de amostras do ar contidas no interior dos recipientes. A concentração de $\mathrm{CO}_{2}$, expressa em $\mathrm{mLL}^{-1}$, foi avaliada em cromatógrafo a gás Hewlett-Packard

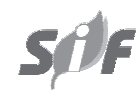

Revista Árvore, Viçosa-MG, v.37, n.1, p.19.29, 2013 


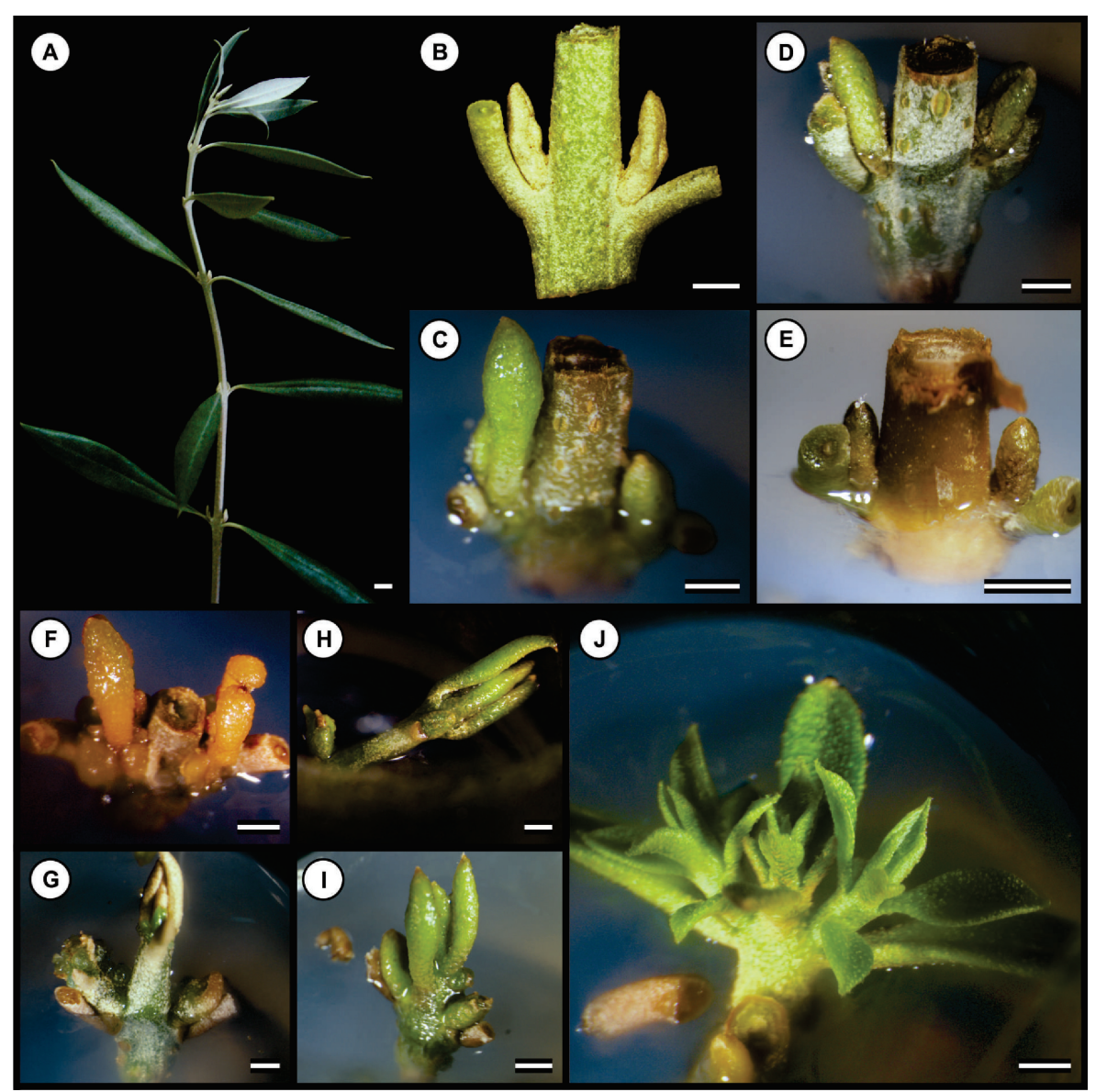

Figura 1 - Estabelecimento in vitro e influência das trocas gasosas na morfogênese in vitro de Olea europaea L. 'Arbequina' (A; B; D; H; I) e 'Maria da Fé' (C; E; F; G; J). (A) Segmento de caule de oliveira com gemas novas. (B) Segmento nodal com duas gemas, utilizado para iniciar o cultivo in vitro. (C-E) Segmentos nodais aos 15 dias de cultivo in vitro com início de intumescimento das gemas. (C) Segmento nodal da cultivar Maria da Fé em meio OM + $20 \mu \mathrm{M}$ de ZEA + tampa com membrana. (D) Segmento nodal de 'Arbequina' em meio OM + $20 \mu \mathrm{M}$ de ZEA + tampa rígida. (E) Segmento nodal de 'Maria da Fé' com início de oxidação em meio OM + $20 \mu \mathrm{M}$ de ZEA + 10 $\mu \mathrm{M}$ de $\mathrm{GA}_{3}+$ tampa com membrana. (F-J) Segmentos nodais aos 30 dias de cultivo in vitro com início de intumescimento das gemas, formação de calos até a formação de plantas. (F) Segmento nodal oxidado de 'Maria da Fé' em meio $\mathrm{OM}+20 \mu \mathrm{M}$ de ZEA + $10 \mu \mathrm{M}$ de GA 3 + tampa rígida. (G) Segmento nodal de 'Maria da Fé' com início de formação de calos em meio OM + $20 \mu \mathrm{M}$ de ZEA + tampa rígida. (H; I) Segmentos nodais de 'Arbequina' em meio OM $+20 \mu \mathrm{M}$ de ZEA + tampa com membrana com gemas intumescidas e formação de plantas. (J) Segmento nodal de 'Maria da Fé' em meio OM + $20 \mu \mathrm{M}$ de ZEA + tampa rígida com formação de plantas.

Figure 1 - In vitro establishment and influence of gaseous exchanges on in vitro morphogenesis of Olea europaea L. cultivars 'Arbequina' (A; B; D; H; I) and 'Maria da Fé' $(C ; E ; F ; G ; J)$. (A) Active growing shoot branch displaying new axillary dormant shoot buds. (B) Nodal segment with two axillary buds used to establish in vitro cultures. (C-E) Nodal segments at 15 days of in vitro culture displaying swelling of buds. (C) Nodal segment of 'Maria da Fé' cultured in OM medium + $20 \mu M Z E A+$ rigid lid with porous membrane. (D) Nodal segment of 'Arbequina' cultured in OM medium + $20 \mu M Z E A+$ rigid lid. (E) Nodal segment of 'Maria da Fé' showing initial oxidation response in $O M$ medium $+20 \mu M Z E A+10 \mu M d e G A+$ rigid lid with porous membrane. $(\boldsymbol{F}-J)$ Nodal segments at 30 days of culture with initial bud swelling, callusing and aerial part formation. (F) Nodal segment of 'Maria da Fé' with oxidation response in OM medium + $20 \mu M Z E A+10 \mu M G A_{3}+$ rigid lid. (G) Nodal segment of 'Maria da $F e ́$ ' with initial callusing response in OM medium + $20 \mu M \mathrm{ZEA}+$ rigid lid. $(\boldsymbol{H} ; \boldsymbol{I})$ Nodal segment of 'Arbequina' in OM medium + $20 \mu M \mathrm{ZEA}+$ lid with membranes with swollen buds and formation of shoots. (J) Nodal segment of 'Maria da Fé' in OM medium + $20 \mu M$ ZEA + rigid lid displaying proliferation of axillary shoots.

Revista Árvore, Viçosa-MG, v.37, n.1, p.19.29, 2013 
5890, série II, com detector de ionização de chama (FID) na temperatura de $150{ }^{\circ} \mathrm{C}$, injetor a $110^{\circ} \mathrm{C}$ e coluna Porapak-N na temperatura de $60^{\circ} \mathrm{C}$, usando-se, como gás de arraste, o dinitrogênio.

\subsection{Influência do tipo de vedação em tubos de ensaio}

Para o estabelecimento in vitro dos segmentos nodais, o meio de cultura utilizado foi composto pelos sais e vitaminas de meio OM (Olive Medium) (RUGINI, 1984) adicionado de $0,2 \mathrm{mg} \mathrm{L}^{-1} \mathrm{de} \mathrm{PVP}$ (polivinilpirrolidona), $20 \mu \mathrm{M}$ de ZEA e na presença e ausência de $10 \mu \mathrm{M}$ de ácido giberélico $\left(\mathrm{GA}_{3}\right)$, totalizando dois meios de cultura. $\mathrm{O}$ pH foi ajustado para 5,8 antes da inclusão de $0,7 \%$ de ágar (Merck ${ }^{\circledR}$, Alemanha) e autoclavado a $121{ }^{\circ} \mathrm{C}$ por $15 \mathrm{~min}$. O regulador de crescimento $\mathrm{GA}_{3}$ foi filtroesterilizado e acrescentado após a autoclavagem do meio de cultura. Foram utilizados tubos de ensaio (25 x $150 \mathrm{~mm}$ ) com $10 \mathrm{~mL}$ de meio de cultura, sendo inoculado um explante por tubo de ensaio. Visando diminuir a oxidação, as culturas foram mantidas em sala de crescimento a $25 \pm 2{ }^{\circ} \mathrm{C}$, no escuro, por dois dias. Após esse período, o material foi mantido sob o fotoperíodo de $16 \mathrm{~h}$ e irradiância de $36 \mu \mathrm{mol} \mathrm{m} \mathrm{m}^{-2} \mathrm{~s}^{-1}$, a $25 \pm 2{ }^{\circ} \mathrm{C}$. Quando completados cinco dias de inoculação, metade dos tubos de ensaio, contendo um segmento nodal, foi vedada com tampas com membrana porosa, seguindo-se a metodologia de Saldanha et al. (2012), para promover as trocas gasosas, totalizando 20 tubos por tratamento.

Os tratamentos foram dispostos em delineamento inteiramente casualizado, em arranjo fatorial $2 \times 2 \times 2$, composto por duas cultivares ('Arbequina' e 'Maria da Fé'), dois meios de cultura (OM + $20 \mu \mathrm{M}$ de ZEA; e $\mathrm{OM}+20 \mu \mathrm{M}$ de $\mathrm{ZEA}+10 \mu \mathrm{M}$ de $\mathrm{GA}_{3}$ ) e dois tipos de vedação (tampa rígida de polipropileno autoclavável sem orifício; e tampa rígida de polipropileno autoclavável com orifício de $12 \mathrm{~mm}$ coberto por membrana porosa, permeáveis às trocas gasosas). Cada repetição foi composta de cinco tubos de ensaio, sendo a unidade experimental constituída de quatro desses tubos (contendo um segmento nodal/tubo), totalizando 20 explantes/tratamento.

Aos 30 dias de cultivo, as respostas morfogenéticas foram avaliadas quanto ao número de gemas intumescidas, número de brotos e porcentagem de oxidação. Os dados foram submetidos à análise de variância e as médias dos tratamentos, comparadas estatisticamente pelo teste de Tukey $(\alpha=0,05)$, por meio do programa estatístico SISVAR (FERREIRA, 2003). Os dados de contagem, como número de gemas intumescidas e número de brotos, foram transformados para $\sqrt{x+0,5}$.

\section{RESULTADOS}

\subsection{Estabelecimento in vitro das cultivares de oliveira}

Após 30 dias de cultivo, constatou-se a contaminação de $15 \%$ e $8,8 \%$ do total dos explantes inoculados das cultivares 'Arbequina' e 'Maria da Fé', respectivamente (Figura 2A). Em relação à porcentagem de contaminação fúngica e bacteriana, foi possível observar que, em 'Arbequina', 33,3\% da contaminação total foi ocasionada por fungos e $66,7 \%$ por bactérias. $\mathrm{Na}$ 'Maria da Fé', do total de 8,8\%, 28,6\% da contaminação total foi por fungos e $71,4 \%$ por bactérias (Figura 2B).

\subsection{Estimativa do número de trocas gasosas por minuto}

Foi possível observar que, ao longo do tempo (de 0 a $20 \mathrm{~min}$ ), houve queda gradual da concentração de $\mathrm{CO}_{2}$ nos tubos com os dois tipos de vedação. No entanto, houve maior redução nos tubos contendo a tampa com membrana porosa. Com isso, observou-se que, nos dois tipos de vedação, ocorrem trocas gasosas, mas nos tubos contendo a tampa com membrana essas trocas são substancialmente maiores, em comparação com a vedação convencional (Figura 3 ).

\subsection{Influência do tipo de vedação em tubos de ensaio}

Pela análise de variância, tanto o número de gemas intumescidas quanto o número de brotos das plantas regeneradas diferiram $(\mathrm{p}<0,05)$ nas interações dos tratamentos, cultivar ('Arbequina' e 'Maria da Fé'), meios de cultura $(\mathrm{OM}+20 \mu \mathrm{M}$ de $\mathrm{ZEA}$; e $\mathrm{OM}+20 \mu \mathrm{M}$ de $\mathrm{ZEA}+10 \mu \mathrm{M}$ de $\mathrm{GA}_{3}$ ) e tipos de vedação (tampa rígida sem orifício; e tampa rígida com orifício de $12 \mathrm{~mm}$ cobertos por membrana porosa). Na variável número de gemas intumescidas, houve diferença estatística para interação meio de cultura e tipos de vedação. Já na variável número de brotos houve diferença apenas em meio de cultura. Na variável porcentagem de oxidação, não houve diferença significativa a $5 \%$ de probabilidade, pelo teste F.

O número médio de gemas produzidas pela planta regenerada de 'Arbequina' foi superior $(\mathrm{p}<0,05)$ ao apresentado pela 'Maria da Fé', quando cultivadas 

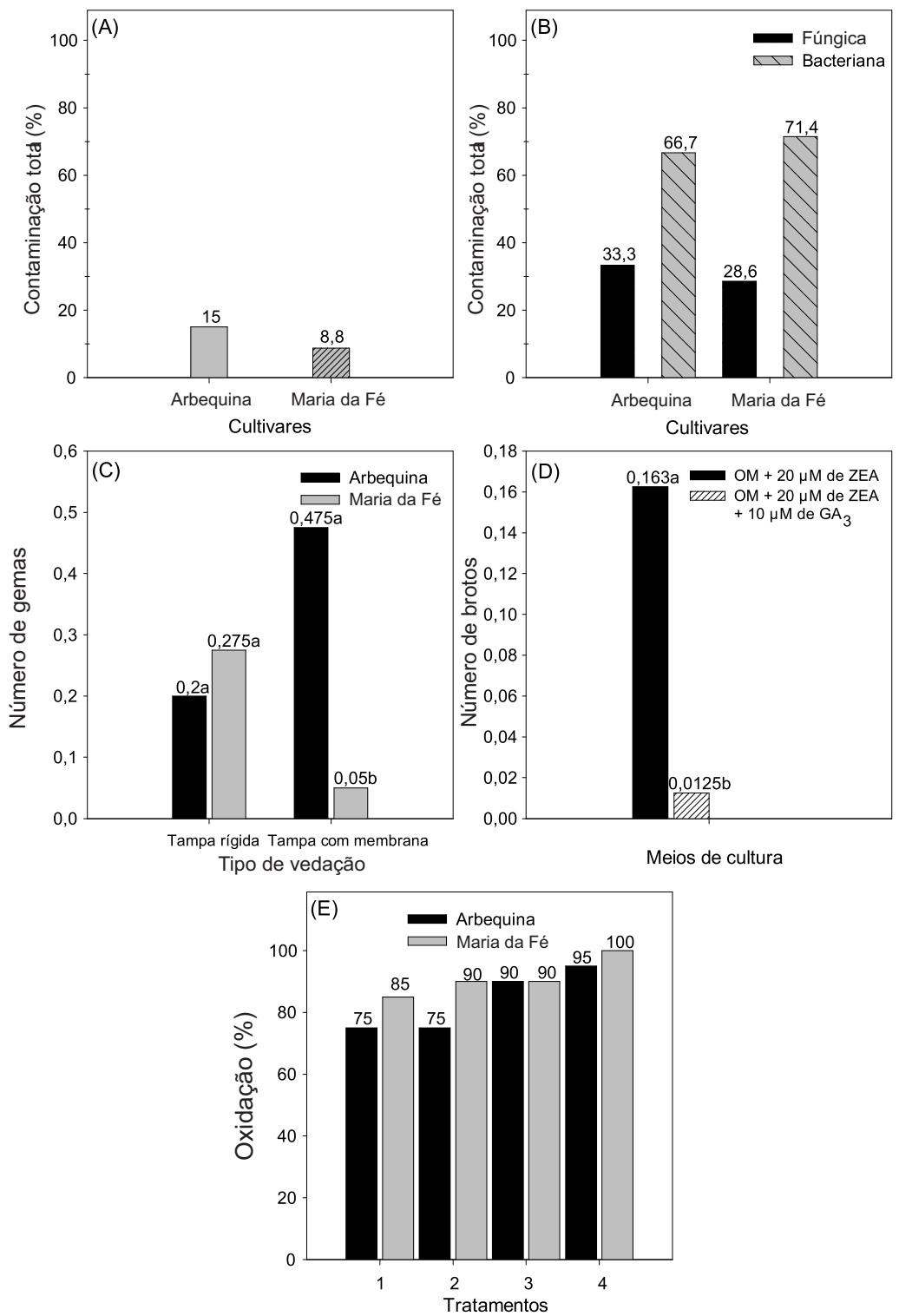

Figura 2 - Porcentagem de contaminação total por cultivar (A); porcentagem de contaminação fúngica e bacteriana em cada cultivar (B); média do número de gemas intumescidas (C); média do número de brotos (D); porcentagem de oxidação dos explantes; e (E) a partir de respostas do estabelecimento in vitro e influência das trocas gasosas na morfogênese in vitro de genótipos de Olea europaea L. (cvs. Arbequina e Maria da Fé) nos diferentes tratamentos $(1-$ Meio OM + $20 \mu \mathrm{M}$ de ZEA + tampa rígida; 2 - Meio OM + $20 \mu \mathrm{M}$ de ZEA + tampa com membrana porosa; $3-$ Meio $\mathrm{OM}+20 \mu \mathrm{M}$ de $\mathrm{ZEA}+10 \mu \mathrm{M}$ de $\mathrm{GA}_{3}+$ tampa rígida; e $4-\mathrm{Meio} \mathrm{OM}+20 \mu \mathrm{M}$ de ZEA + $10 \mu \mathrm{M}$ de $\mathrm{GA}_{3}+$ tampa com membrana porosa), avaliados aos 30 dias de cultivo in vitro. Médias seguidas de letras diferentes em cada tratamento diferem entre si, pelo teste de Tukey a $5 \%$ de probabilidade.

Figure 2 - Percentage of total contamination (A); Percentages of bacterial and fungal contamination (B); Mean number of responsive swollen axillary buds $(\boldsymbol{C}) ;$ Mean number of axillary shoots $(\boldsymbol{D})$; and percentage of oxidation $(\boldsymbol{E})$ during in vitro establishment of Olea europaea L. cvs. 'Arbequina' and 'Maria da Fé' nodal explants as affected by gas exchange and different medium $(1-O M$ medium $+20 \mu M Z E A+$ rigid lid; $2-O M$ medium $+20 \mu M$ $Z E A+$ lid with porous membrane; 3 - OM medium + $20 \mu M Z E A+10 \mu M G A_{3}+$ rigid lid; and 4 -OM medium $+20 \mu M Z E A+10 \mu M G A_{3}+$ lid with porous membrane), evaluated at 30 days of in vitro culture. Means followed by different letters, within the same treatment, differ statistically by Tukey test at $5 \%$ probability.

Revista Árvore, Viçosa-MG, v.37, n.1, p.19.29, 2013 


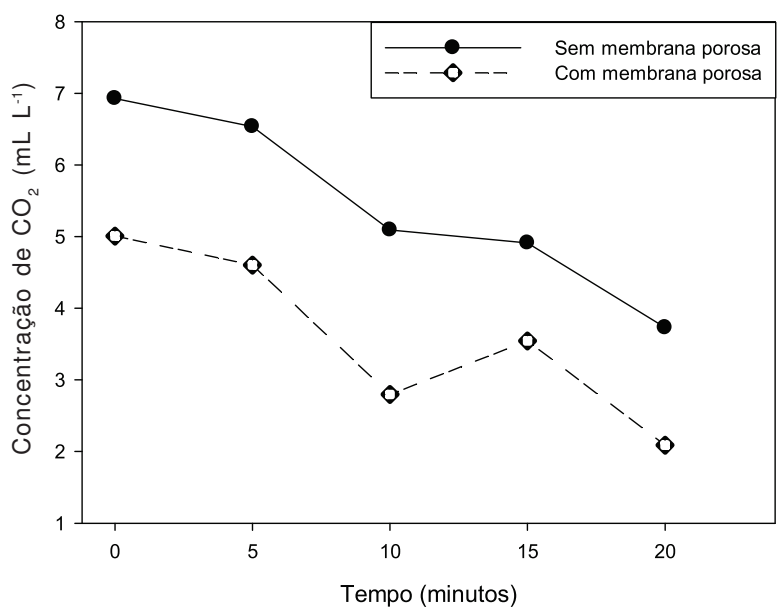

Figura 3 - Mensuração das trocas gasosas em tubos de ensaio, a partir da concentração de $\mathrm{CO}_{2}$, com dois tipos de vedação (tampa rígida de polipropileno autoclavável sem orifício; e tampa rígida de polipropileno autoclavável com orifício de $12 \mathrm{~mm}$ cobertos por membrana porosa, permeáveis às trocas gasosas), nos tempos de $0,5,10,15$ e $20 \mathrm{~min}$.

Figure 3 - Measurement of gas exchange in test tubes from the $\mathrm{CO}_{2}$ concentration, with two types of sealing (rigid lid polypropylene autoclavable without orifice and rigid lid polypropylene autoclavable with $12 \mathrm{~mm}$ hole covered by porous membrane) at times 0 , 5, 10. 15, 20 minutes.

nos tubos vedados com tampa com membrana porosa. No entanto, quando se utilizou a tampa rígida, não houve diferença estatística significativa entre as cultivares, sendo as médias bem inferiores, quando comparadas ao sistema com membrana (Figura 2C).

Considerando a variável número de brotos, observou-se que o meio OM acrescido de $20 \mu \mathrm{M}$ de ZEA tem influência positiva sobre o desenvolvimento de brotos, sendo esse meio superior estatisticamente $(\mathrm{p}<0,05)$ ao meio OM acrescido de $20 \mu \mathrm{M}$ de ZEA e $10 \mu \mathrm{M}$ de $\mathrm{GA}_{3}$ (Figuras 2D e 1H-J). Na variável porcentagem de oxidação, não houve diferença estatística significativa entre os tratamentos (Figura 2E).

\section{DISCUSSÃO}

\subsection{Estabelecimento in vitro das cultivares de oliveira}

As porcentagens de contaminação encontradas neste trabalho situaram-se dentro dos limites aceitáveis quando comparadas a outros métodos utilizados para o estabelecimento da cultura da oliveira in vitro. Como é o caso dos protocolos sugeridos por Zacchini e De Agazio (2004), utilizaram-se diferentes procedimentos de estabelecimento de brotos axilares e segmentos nodais de O. europaea L. 'Nebbiara'. Esses autores relataram que o procedimento de $70 \%$ de álcool seguido de hipoclorito de sódio $15 \%$ foi insatisfatório em ambos os explantes utilizados. Quando usaram $0,1 \%$ de bicloreto de mercúrio, seguido de hipoclorito de sódio $15 \%$, esses autores mencionaram que houve $75 \%$ de contaminação e, quando adicionaram antibióticos ao meio de cultura, essa porcentagem decresceu para $14 \%$.

Já Donini et al. (2008a), visando diminuir a contaminação in vitro de $O$. europaea L. 'Arbequina', pulverizaram Agrimicina e Cercobin nas mudas mantidas em casa de vegetação. Após esse processo, esses autores utilizaram o procedimento-padrão de $70 \%$ de álcool e hipoclorito de sódio 2,5\% de cloro ativo em câmara de fluxo laminar. Ainda assim, relataram contaminações nos meios MS, MO e WPM de natureza fúngica, 92,95\%, $75,71 \%$ e $67,56 \%$; e bacteriana, $2,37 \%, 1,33 \%$ e $0,32 \%$, respectivamente. Diferente do observado neste trabalho, as contaminações mais abundantes foram por bactérias. Além disso, a ocorrência de contaminantes in vitro pode ser de ocorrência da má manipulação das culturas em câmara de fluxo laminar, por protocolo ineficiente de descontaminação ou por contaminantes endógenos à planta. Dessa forma, o meio de cultura não tem influência direta sobre as contaminações encontradas em condições in vitro, diferente do que relataram Donini et al. (2008a).

Em virtude do baixo índice de contaminação in vitro das cultivares de oliveira 'Arbequina' e 'Maria da Fé' obtidas neste trabalho (Figura 2A-B), sugere-se a utilização do protocolo de desinfestação desenvolvido neste trabalho.

\subsection{Influência do tipo de vedação em tubos de ensaio}

Após 15 dias de cultivo, observou-se o início da morfogênese in vitro 'Arbequina' e 'Maria da Fé' (Figura 1C-D). No entanto, também foi observado o início de oxidação nas duas cultivares (Figura 1E).

Após 30 dias de cultivo, foi possível observar a ocorrência da produção de calos de coloração verde em apenas uma repetição da cultivar 'Maria da Fé', em meio OM + $20 \mu \mathrm{M}$ de ZEA com tampa rígida (Figura $1 G)$. No entanto, não houve morfogênese a partir desses calos. Trabelsi et al. (2011) observaram que o meio

Revista Árvore, Viçosa-MG, v.37, n.1, p.19.29, 2013 
OM suplementado com 2,5 $\mu$ M de ZEA não foi suficiente para maturar os calos embriogênicos de O europaea L. 'Chetoui', sendo necessário associar aquela concentração de ZEA com 2,5 $\mu \mathrm{M}$ de 2,4-D (ácido 2,4-diclorofenoxiacético), para que houvesse a maturação dos embriões. Dessa forma, neste trabalho pode ser necessária a associação de outros reguladores de crescimento para que ocorra a morfogênese desses calos.

Para 'Arbequina', em relação ao maior número de gemas formadas no tratamento cujos tubos foram vedados com tampa rígida, provavelmente o resultado encontrado possa ser explicado pelo acúmulo de etileno nos referidos tubos. O mesmo foi observado por Rodrigues et al. (2011), os quais encontraram que nos frascos com membranas porosas houve trocas gasosas, evitando, assim, o acúmulo do gás etileno dentro dos frascos, sendo observado o oposto nos frascos com tampa rígida sem orifício. No entanto, Zobayed et al. (2000) observaram que o uso das membranas porosas não é capaz de remover completamente a concentração do gás etileno produzido pelas plantas in vitro. Apesar disso, neste trabalho, provavelmente se faz necessária a vedação tradicional para a emissão de novas gemas da cultivar 'Maria da Fé', já que o número de gemas decresceu quando os tubos foram vedados com tampas com membrana.

Diferente do que foi observado por Rodrigues et al. (2011), que relataram que o uso de tampas com membranas porosas influenciaram positivamente o estabelecimento das culturas, além de aumentarem a qualidade e quantidade de brotos e diminuírem a ocorrência de clorose e senescência nas folhas de Azadirachta indica A. Juss. Foi o que observaram Ribeiro et al. (2009) em Solanum melongena L., em que as plantas mantidas no mesmo tipo de vedação (tampas com membranas porosas) apresentaram-se maiores e mais vigorosas, além de apresentarem folhas e raízes maiores e mais desenvolvidas.

Zobayed (2006) relatou que o crescimento e desenvolvimento de plantas ou explantes produzidos in vitro podem ser afetados pela composição da atmosfera gasosa dos recipientes. Ou seja, o uso de membranas porosas favorece as trocas gasosas, o que irá aumentar a concentração de $\mathrm{CO}_{2}$ e decrescer a concentração de etileno e os níveis de umidade relativa, influenciando positivamente o crescimento das plantas (FAL et al., 1999; ZOBAYED et al., 2002; GONÇALVES et al., 2008; XIAO et al., 2011).

Nepomuceno et al. (2009) acrescentaram ainda que, além de favorecer o crescimento das plantas in vitro, o uso de um sistema de aeração proporciona incrementos significativos no controle da abscisão foliar. Além disso, o uso de membranas porosas é capaz de afetar positivamente a aclimatização e crescimento das plantas ex vitro, ou seja, aumenta a taxa de sobrevivência das plantas (ZOBAYED et al., 2000; SHIM et al., 2003), pois essa condição favorece a diminuição da perda de água durante a transferência para condições ex vitro, devido à elevada deposição de cera epicuticular e à produção de estômatos funcionais (MAJDA et al., 1997)

Considerando a variável número de brotos, assim como neste trabalho, Donini et al. (2008b) também observaram que a combinação de reguladores de crescimento entre ZEA e GA 3 não foi eficaz para o estabelecimento de 'Arbequina'. No entanto, Grigoriadou et al. (2002) verificaram que a combinação de $20 \mu \mathrm{M}$ de ZEA com $10 \mu \mathrm{M}$ de $\mathrm{GA}_{3}$ aumentou o número de brotações por explante no cultivo de oliveira 'Hondrolia Chalkidikis'. Alguns autores relataram ainda que a utilização do meio OM adicionado de $18 \mu \mathrm{M}$ de zeatina (ZEA) favoreceu o maior número de brotações em oliveira (BINET et al., 2007; ALI et al., 2009). Já Gomes et al. (2010) constataram que o acréscimo de $10,97 \mu \mathrm{M}$ e de $16,46 \mu \mathrm{M}$ de $\mathrm{GA}_{3}$ induz apenas o crescimento dos brotos e a formação de calos na base do explante.

Zacchini e De Agazio (2004) e García et al. (2002) utilizaram a concentração de 4,56 $\mu \mathrm{M}$ de ZEA para a proliferação de brotos nas cultivares 'Nebbiara' e 'Manzanillo', respectivamente. No entanto, Brito et al. (2009), Brito e Santos (2009) e Brito et al. (2010) utilizaram meio OM suplementado com 9,12 $\mu \mathrm{M}$ de ZEA para a proliferação de brotos de oliveira.

Já na variável porcentagem de oxidação se observou que a menor porcentagem de oxidação ocorreu em meio $\mathrm{OM}+20 \mu \mathrm{M}$ de ZEA nos dois tipos de vedação e nas duas cultivares, 'Arbequina' e 'Maria da Fé'. No entanto, as maiores porcentagens de oxidação foram encontradas na adição de $\mathrm{GA}_{3}$ ao meio de cultura (Figuras 2E e 1F).

Shibli et al. (2001) e Khan et al. (2002b) utilizaram 0,2 $\mathrm{g} \mathrm{L}^{-1}$ de PVP para prevenir, com sucesso, a oxidação por exsudados fenólicos das cultivares $O$. europaea L. 'Nabali' e 'Leccino', respectivamente, ou seja, 10 vezes

Revista Árvore, Viçosa-MG, v.37, n.1, p.19.29, 2013 
a mais que a concentração de PVP utilizada neste trabalho. Dessa forma, o aumento da concentração de PVP poderia prevenir a oxidação dos explantes das cultivares 'Arbequina' e 'Maria da Fé'. Khan et al. (2002a) acrescentaram que a utilização de ácido cítrico e ácido ascórbico, ao final da descontaminação, não diminuiu a taxa de oxidação dos explantes. O mesmo foi observado neste trabalho, em que a passagem dos explantes em solução de ácido cítrico e ácido ascórbico não diminuiu a porcentagem de oxidação dos explantes das cultivares 'Arbequina' e 'Maria da Fé'.

As plantas lenhosas, incluindo a maioria das plantas frutíferas, apresentam dificuldades para o estabelecimento in vitro em razão, principalmente, da oxidação e contaminação dos explantes. Neste trabalho, a baixa concentração utilizada de PVP e a permanência de 30 dias no mesmo meio de cultura influenciaram o aumento da porcentagem de oxidação dos explantes in vitro (Figura 1E-F).

O procedimento descrito neste estudo abre novas possibilidades para a utilização de tampas rígidas com orifícios cobertos por membranas porosas em $O$. europaea L., pois esse sistema tem papel importante na morfogênese in vitro dessa espécie. Além disso, o uso dessas membranas porosas pode beneficiar o intumescimento das gemas e a posterior formação de plantas de oliveira, o que irá adaptá-las durante o transplantio e aumentar a porcentagem de sobrevivência durante a aclimatização ex vitro.

\section{CONCLUSÃO}

O subcultivo dos explantes das cultivares 'Arbequina' e 'Maria da Fé' a cada 15 dias no mesmo meio de cultura, juntamente com o aumento da concentração do PVP, previne a oxidação dos explantes.

A utilização do meio OM acrescido de $20 \mu \mathrm{M}$ de zeatina aumentou a morfogênese in vitro dos explantes das duas cultivares de O. europaea, 'Arbequina' e 'Maria da Fé'.

O uso de membranas porosas, que permite as trocas gasosas entre o interior e o exterior dos frascos, influenciou positivamente a morfogênese in vitro da cultivar 'Arbequina', enquanto na cultivar 'Maria da Fé' o uso da vedação tradicional é a mais adequada, confirmando que a morfogênese in vitro de O. europaea é genótipo dependente.

\section{AGRADECIMENTOS}

À Coordenação de Aperfeiçoamento de Pessoal de Nível Superior (CAPES), pela concessão da bolsa de estudo; e ao Conselho Nacional de Desenvolvimento Científico e Tecnológico (CNPq), pelo apoio financeiro.

Ao professor Fernando Luiz Finger (Laboratório de Pós-Colheita, do Departamento de Fitotecnia) por disponibilizar o equipamento cromatógrafo a gás HewlettPackard 5890, série II. E ao Diego Silva Batista pela análise das trocas gasosas.

\section{REFERÊNCIAS}

ACEBEDO, M. M. et al. In vitro germination of embryos for speeding up seedling development in olive breeding programmes. Scientia Horticulturae, v. 69, n.3-4, p.207-215, 1997.

ALI, A. et al. Effect of different media and growth regulators on in vitro shoot proliferation of olive cultivar 'Moraiolo'. Pakistan Journal of Botany, v.41, n.2, p.783-795, 2009.

BINET, M. N. et al. Micropropagation of olive (Olea europaea L.) and application of mycorrhiza to improve plantlet establishment. In Vitro Cellular \& Developmental Biology Plant, v.43, n.5, p.473-478, 2007.

BRITO, G. et al. Large-scale field acclimatization of Olea maderensis micropropagated plants: morphological and physiological survey. Trees, v.23, n.5, p.1019-1031, 2009.

BRITO, G. et al. Assessment of genetic stability of two micropropagated wild olive species using flow cytometry and microsatellite markers. Trees, v.24, p.723-732, 2010.

BRITO, G. et al. Genetic characterisation of olive trees from Madeira Archipelago using flow cytometry and microsatellite markers. Genetic Resources and Crop Evolution, v.55, n.5, p.657-664, 2008.

BRITO, G.; SANTOS, C. Basal medium improvement for routine micropropagation of Olea maderensis: physiological comparative studies. Canadian Journal of Forest Research, v.39, n.4, p.814-822, 2009.

Revista Árvore, Viçosa-MG, v.37, n.1, p.19.29, 2013

Revista Árvore, Viçosa-MG, v.37, n.1, p.19.29, 2013

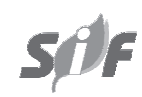


DONINI, L. P. et al. Estabelecimento in vitro de oliveira cv. "Arbequina" para início da micropropagação. Ciência Rural, v.38, n.6, p.1769-1772, 2008a.

DONINI, L. P. et al. Avaliação da resposta de três cultivares de oliveira ao cultivo in vitro sob diferentes comprimentos de onda luminosa e efeitos da combinação de zeatina e ácido giberélico. Scientia Agraria, v.9, n.2, p.229-233, 2008b.

FAL, M. A. et al. Differences between Dianthus caryophyllus L. cultivar in in vitro growth and morphogenesis are related to their ethylene production. Plant Growth Regulation, v.27, n.2, p.131-136, 1999.

FERREIRA, D. F. Programa de análises estatísticas (Statistical Analysis

Software) e planejamento de experimentos. SISVAR 5.0 (Build 67). 2003. Disponível em: <http://www.dex.ufla.br/ $\sim$ danielff/softwares.htm $>$.

GARCÍA, J. L. et al. Influence of carbon source and concentration on the in vitro development of olive zygotic embryos and explants raised from them. Plant Cell, Tissue and Organ Culture, v.69, p.95-100, 2002.

GOMES, G. A. C. et al. Micropropagation of Maclura tinctoria L. an endangered woody species. Revista Árvore, v.34, n.1, p.25-30, 2010 .

GONÇALVES, L. A. et al. In vitro propagation of Herreria salsaparilha Martius

(Herreriaceae) as affected by different sealing materials and gaseous exchanges. Plant Cell, Tissue and Organ Culture, v.92, n.3, p.243-250, 2008.

GRIGORIADOU, K.; VASILAKAKIS, M.; ELEFTHERIOU, E. P. In vitro propagation of the Greek olive cultivar 'Chondrolia Chalkidikis' Plant Cell, Tissue and Organ Culture, v.71, n.1, p.47-54, 2002.

KHAN, M. R.; RASHID, H.; QURAISHI, A. Development of aseptic protocols in olive (Olea europaea L.) cv. Pendollino. Asian Journal of Plant Sciences, v.1, p.220-221, 2002a.

Revista Árvore, Viçosa-MG, v.37, n.1, p.19.29, 2013
KHAN, M. R.; RASHID, H.; QURAISHI, A. In vitro Shoot Development from Juvenile Cuttings of Field-Grown Olive (Olea europaea L.) cv. Leccino. OnLine Journal of Biological Sciences, v.2, n.7, p.438-440, 2002b.

KOZAI, T.; KUBOTA, C. Development a photoautotrophic micropropagation system for woody plants. Journal of Plant Research, v.114, p.525-537, 2001.

LOPES, T. et al. Determination of genetic stability in long-term somatic embryogenic cultures and derived plantlets of cork oak using microsatellite markers. Tree Physiology, v. 26, p.1145-1152, 2006.

LOUREIRO, J. et al. Nuclear DNA content estimations in wild olive (Olea europaea L. ssp. europaea var. sylvestris Brot.) and Portuguese cultivars of $O$. europaea using flow cytometry. Genetic Resources and Crop Evolution, v.54, p.21-25, 2007.

MAJDA, J. P. et al. The effect of ventilation rate on proliferation and hyperhydricity of Dianthus caryophyllus L. In Vitro Cellular \&

Developmental Biology - Plant, v.33, p.62-69, 1997.

NEPOMUCENO, C. F. et al. Respostas morfofisiológicas in vitro de plântulas de Anadenanthera colubrina (Vell.) Brenan var. cebil (Griseb) Altschul. Revista Árvore, v.33, n.3, p.481-490, 2009.

NGUYEN, Q. T.; KOZAI, T. Photoautotrophic micropropagation of woody species. In: KOZAI, T.; AFREEN, F.; ZOBAYED, S. M. A. (Eds.).

Photoautotrophic (sugar-free medium) micropropagation as a new micropropagation and transplant production system. Dordrecht: Springer, 2005. p.123-146.

OLIVEIRA, A. F.; ANTUNES, L. E. C.; SCHUCH, M. W. Caracterização morfológica de cultivares de oliveira em coleção e considerações sobre o seu cultivo no Brasil. Informe Agropecuário, v.27, n.231, p.55-62, 2006.

OLIVEIRA, A. F. et al. Influência do número de nós em estacas semilenhosas de oliveira (Olea europaea L.) no enraizamento sob câmara de nebulização. Ciência Agrotécnica, v.27, n.2, p.332-338, 2003. 
PÉREZ-BARRANCO, G. et al. Studies on genetic transformation of olive (Olea europaea L.) somatic embryos: I. Evaluation of different aminoglycoside antibiotics for nptII selection; II. Transient transformation via particle bombardment. Plant Cell, Tissue and Organ Culture, v.97, n.3, p.243-251, 2009.

RIBEIRO, A. P. O. et al. The influence of flask sealing on in vitro morphogenesis of eggplant (Solanum melongena L.). In Vitro Cellular \& Developmental Biology - Plant, v.45, n.4, p.421-428, 2009.

RODRIGUES, M. et al. Effects of flask sealing and growth regulators on in vitro propagation of neem (Azadirachta indica A. Juss.). In Vitro Cellular \& Developmental Biology Plant, 2011. DOI: 10.1007/s11627-011-9398-8 (Online First ${ }^{\mathrm{TM}}$, 23 September 2011).

RUGINI, E. In vitro propagation of some olive (Olea europaea sativa L.) cultivars with different rootability, and medium development using analytical data from developing shoots and embryos. Scientia Horticulturae, v.24, n.2, p.123-134, 1984.

RUGINI, E. Somatic embryogenesis in olive (Olea europaea L.). In: JAIN, S. M.; GUPTA, K.; NEWTON, J. (Ed.). Somatic embryogenesis in woody plants. Dordrecht: Kluwer, 1995. p.171-189.

RUGINI, E.; BIASI, R.; MULEO, R. Olive (Olea europea var. sativa) transformation. In: JAIN, S. M.; MINOCHA, S. C. (Ed.). Molecular Biology of Woody Plants. Dordrecht: Kluwer Academic Publishers, 2000. p.245-279.

RUGINI, E.; GUTIÉRREZ-PESCE, P. Genetic improvement of olive. Pomologia Croatica, v.12, p.43-74, 2006.

SALDANHA, C. et al. A low-cost alternative membrane system that promotes growth in nodal cultures of Brazilian ginseng [Pfaffia glomerata (Spreng.) Pedersen]. Plant Cell, Tissue and Organ Culture, p.1-10, 2012. DOI: 10.1007/ s11240-012-0162-5 (Online First ${ }^{\mathrm{TM}}$, 04 may 2012)
SHIBLI, R. A. et al. Somatic embryogenesis and plant recovery from callus of 'Nabali' Olive (Olea europea L.). Scientia Horticulturae, v.88, p.243-256, 2001.

SHIM, S. W.; HAHN, E. J.; PAEK, K. Y. In vitro and ex vitro growth of grapevine rootstock ' $5 \mathrm{BB}$ ' as influenced by number of air exchanges and the presence or absence of sucrose in culture media Plant Cell, Tissue and Organ Culture, v.75, n.1, p.57-62, 2003.

TRABELSI, E. B. et al. Somatic embryogenesis in cell suspension cultures of olive Olea europaea (L.) 'Chetoui'. Acta Physiologiae Plantarum, v.33, p.319-324, 2011.

VIEIRA NETO, J. et al. Aspectos técnicos da cultura da oliveira. Belo Horizonte: Epamig, 2008. 56p. (Boletim Técnico)

XIAO, Y.; NIU, G.; KOZAI, T. Development and application of photoautotrophic micropropagation plant system. Plant Cell, Tissue and Organ Culture, v.105, p.149-158, 2011.

ZACCHINI, M.; DE AGAZIO, M.

Micropropagation of a local olive cultivar for germplasm preservation. Biologia

Plantarum, v.48, n.4, p.589-592, 2004.

ZOBAYED, S. Aeration in plant tissue culture. In: DUTTA GUPTA, S.; IBARAKI, Y. (Ed.). Plant tissue culture engineering. Springer: 2006. p.313-327.

ZOBAYED, S. M. A. et al. Mass propagation of Eucalyptus camaldulensis in a Scaled-up vessel under In Vitro photoautotrophic condition.

Annals of Botany, v.85, n.5, p.587-592, 2000.

ZOBAYED, S. M. A.; ARMSTRONG, J.;

ARMSTRONG, W. Multiple shoot induction and leaf and flower bud abscission of Annona cultures as affected by types of ventilation. Plant Cell, Tissue and Organ Culture, v.69, n.2, p.155-165, 2002. 
